\title{
THE POMERANIAN REGION: PARTIES AND THE PARTY STRUCTURE OF THE VOIVODESHIP SEJMIK AFTER 1998
}

\author{
by Beata Słobodzian
}

The elections are an important element of the political system; indicator of the proper functioning of a democratic state. It is also the method for selection of the persons who will hold certain positions, public offices ${ }^{1}$ and will represent the interests of the electorate.

The elections have, among others, such functions as: ${ }^{2}$

a) the representatives of various public institutions (government, parliament, local authority) are elected through them;

b) it is a legitimization procedure (authorization) of the authority system;

c) political preferences of voters are articulated during the electoral process;

d) elections constitute a peculiar form of control, evaluation and settling an account with elects.

Modern democratic states cannot function effectively without the electoral process, and thus without the citizens' involvement in this proc-

\footnotetext{
1 A. Antoszewski, R. Herbut (eds.), Leksykon politologii, Wrocław 2002, pp. 499-500.

2 M. Cześnik, Partycypacja wyborcza w Polsce, Warszawa 2007, pp. 1914-1916; Partcypacja wyborcza Polaków, Warszawa 2009, p. 3.
} 
ess. The public is guaranteed a real influence on the process of governance. ${ }^{3}$ Electoral Involvement (Participation) is essential for the realization of the elementary principles of democracy - equality. ${ }^{4}$

Adopted election rules (laws) have the great importance for the quality of elections. Democratic theorist Giovanni Sartori states that "participation, appropriate and reasonably understood, is personally involved, active and willing involving. Participation is not so prosaic «being part of something» (usually being involved in any event), and much less not wanted, forced inclusion to something. Participation is a spontaneous movement, the exact opposite of being involved in the movement (of someone else's will), that is the opposite of mobilization." 5

The participants of the electoral process are the citizens holding the rights that derive from the possession of active and/ or passive voting rights. The electoral participation is characterized by a diversity of organizational form of the electorate. They participate in the process of collegial organizational structures (e.g. political party, associations, social organizations) or "individually" - as the voters.

The article concerns the participation of political parties in the local elections at the regional level in the years 1998-2010, in the Pomeranian Province. It tries to answer the question -why and to what extent the political parties dominate (as the subjects entitled to the nomination of candidates) in the elections to the regional council.

Due to changes in the electoral law it was important to characterize electoral law rules for elections in 1998, 2002, 2006 and 2010.

The political transformation program, which started in 1989 in Poland, covered the reconstruction of structures for local government. The district was established by the Local Government Act of March 8, 1990, ${ }^{6}$ and is the basic unit of the local government. Continuation of reactivating the

3 A. Żukowski, Systemy wyborcze. Wprowadzenie, Olsztyn 1997, p. 11; A. Antoszewski, R. Herbut, Systemy polityczne współczesnego świata, Gdańsk 2001, pp. 207-229.

4 M. Cześnik, Partycypacja wyborcza Polaków, Warszawa 2007, pp. 182-183.

5 G. Sartori, Teoria demokracji, Warszawa 1998, p. 148.

6 Ustawa z dnia 8 marca 1990 r. o samorządzie terytorialnym, Dz.U. $1990 \mathrm{nr} 16$ poz. 95[Local Government Act of March 8, 1990, Journal of Laws of the Republic of Poland, No. 16 of 1990, item 95]. 
next levels of self-government effected in adopting provisions of public administration reform of 1998 . $^{7}$ It was connected with the introduction, on January 1, 1999, the fundamental three-tier territorial division of the country and the establishment, next to the existing self-governed districts, the self-government county and the provincial self-government. The new administrative map consisted of 16 provinces, 308 country districts, 65 township districts (cities with county rights) and 2489 boroughs. ${ }^{8}$

The province with new administrative boundaries has developed as the largest unit of administrative division of the state, regional self-government. Implementation of the new territorial division was connected with the election and selection of the territorial representatives to the newly created local government structures. The Act of July 16, 1998 - Electoral Law for the Provincional, District and Sub-district Council Elections - was an essential act of legislation, conditioning the course of the elections. ${ }^{9}$ The date of the local elections was appointed on October 11, 1998.

Detailed rules of regional councils elections have been included in the Section 4 - Regional Council Election. Specific provisions have been included in Articles 157-181 of the Act. The proportional electoral system using the d'Hondt method of seat allocation between the electoral registers

\footnotetext{
7 See: B. Słobodzian, Współczesny system samorządu terytorialnego w Polsce, Toruń 2007, pp. 46-133.

8 Ustawa z dnia 5 czerwca 1998 r. o samorządzie powiatowym, Dz.U. $1998 \mathrm{Nr} 91$ poz. 678 [District government Act of June, 5 1998, Journal of Laws of the Republic of Poland No. 91 of 1998, item 578; Ustawa z dnia 5czerwca 1998 r. o administracji rządowej w województwie, Dz.U. 1998 Nr 91 poz. 577 [Province Government Administration Act of June, 5 1998, Journal of Laws of the Republic of Poland No. 91 of 1998, item 577]; Ustawa z dnia 24 lipca 1998 r. o wprowadzeniu zasadniczego trójstopniowego podziału terytorialnego państwa, Dz.U. 1998 Nr 96 poz. 603 [Fundamental Three-Tier Territorial Division of the Country Act of July, 241998 on, Journal of Laws of the Republic of Poland No. 96 of 1998, item 603]; Rozporządzenie Rady Ministrów z dnia 7 sierpnia 1998 w sprawie utworzenia powiatów, Dz.U. Nr103, poz. 652 [The Regulation of the Council of Ministers of 7 August 1998 on establishing districts, Journal of Laws of the Republic of Poland No. 103 of 1998 item 652].

9 Ustawa z dnia 16 lipca 1998 r. - Ordynacja wyborcza do rad gmin, rad powiatów i sejmików województw, Dz.U. 1998 Nr 95 poz. 602 [Electoral Law for the Provincional, District and Sub-district Council Elections Act of 16 July, 1998, Journal of Laws of the Republic of Poland No. 95 of 1998, item 602].
} 
(Article 162, 178) was applied in this election. There was an established "barrier" clause for protection against too much political fragmentation in the regional councils. It stated that only those, who won at least $5 \%$ of the valid votes in the whole province range (Article 162), may take part in the distribution of seats. The constituencies were created, where 5 to 15 councillors were selected, and if the district was the constituency, then councillors in the number equal to or greater than $3 / 5$ of the total number of the given council (Article 164), could not be elected. Candidates applying for a councillor's seat were required to collect at least 300 signatures on the list of candidates. Each electoral committee had the right to propose only one list of candidates to regional council in the constituency (Article 169 paragraph. 2). The requirement for establishment of the election committee of electors amounting at least to 5 people was the novelty in the process of nominating candidates.

Institutionalized procedures for nominating candidates, among others through the establishment of the electoral committee along with the designation of his plenipotentiary was not encouraging choice for candidates from outside the party structures and social organizations. ${ }^{10}$ The procedure for appointment, and registration of election committees of voters did not lead to increase voters' interest to exercise passive electoral rights.

Number of regional councils depended on the number of inhabitants of the region: in the provinces up to 2 million residents, the regional council consisted of 45 councillors, and for every 500 thousand, the composition of the regional council increased by a further five councillors (Article 160).

8 constituencies were created for the regional council elections in Pomeranian Province in 1998, in total 50 councillors have been elected from nominated candidates in 40 electoral registers. There were registered 9 electoral registers in Pomeranian regional council elections (the electoral register number and the short for the committee name):11

10 K.A. Piasecki, Wybory parlamentarne, samorządowe, prezydenckie 1989-2002, Toruń 2004, p. 166.

11 Declaration of Provincial Electoral Commissioner of October, 19 1998, on the results of council elections in the Pomeranian province and the Pomeranian Regional 
(1) Democratic Left Alliance (SLD)

(2) Solidarity Electoral Action (AWS)

(3) Freedom Union (UW)

(4) Social Alliance (PS) - an electoral coalition which included Polish People's Party, Labour Union, the National Party of Retirees and Pensioners and the Self-Defence of the Republic of Poland

(5) Movement for Reconstruction of Poland (ROP)

(6) Polish Family (RP)

(7) Christian Democracy of the $3^{\text {rd }}$ Polish Republic (ChD III RP)

(8) The Real Politics Union (UPR)

(9) Zaborska Land Alliance 2010, Brusy (PZZ)

The voting results were established on the basis of protocols received from election commissions. The statutory requirement was to obtain at least $5 \%$ of valid votes in regional council elections. The right to participate in the distribution of seats in the districts was given to: (1) SLD (2) AWS, (3) UW (4) PS:12

Analyzing the results of the local elections to the Pomeranian regional council in 1998, we can state that:

a) a requirement for appointing electoral committees of electors during appointing councillor candidates made it difficult, for persons from outside the party structure or the social organizations, to run for the seat;

b) the principle of proportional allocation of seats, $5 \%$ electoral threshold and the mathematical formula for counting of the votes (the d'Hondt method) encouraged participation of political parties (their Coalitions), public organizations but not the local electoral committees $^{13}$ (Table 1).

Parliamentary elections of September 23, 2001 brought victory to the coalition of parties SLD-UP (Democratic Left Alliance-Labour Union), which announced the change of the electoral rules for local government authorities. New solutions "revolutionized" local government electoral

Assembly held on October, 11 1998, Official Journal according to 1998, No. 73, item. 370, p. 1 .

12 Ibidem, pp. 985-988.

13 K.A. Piasecki, op. cit, pp. 166-168. 
system. New electoral act was passed - the Act of June 20, 2002 on direct elections of borough administrators and mayors and. ${ }^{14}$ The election statute law act was amended by the supplement to Chapter 10 on Electoral Committees (section 10a with the Articles 64a-64 was added). Many rules governing the election campaign were introduced, among others: ${ }^{15}$ prohibition of election campaigns in schools towards students without the voting right, serving alcohol during the conclusion of the election campaign and it was forbidden to make the results of pre-election polls public before the end of voting.

Significant changes involve more accurate regulation of campaign financing principles by introducing rules defining that:

- the financial plenipotentiary of election committee conducts and is responsible for financial management of the election committee, submits election report;

- the total sum of contributions from the natural persons for the election committee and election expenses limit is incurred by the election committees;

- it is forbidden to conduct public collections of money, issuing "donation certificates," accepting funds from anonymous donors.

The right to form election committees was allocated to political parties and coalitions, public organizations and voters (in groups of at least 5 people). There was a duty to notify the competent electoral body about the formation of electoral committee. The committees appointed, from among its members, persons, acting as committee plenipotentiary and a committee financial plenipotentiary (in the municipalities with up to 20 thousand inhabitants the responsibilities of the financial plenipotentiary

14 Ustawa z dnia 20 czerwca 2002 r. o bezpośrednim wyborze wójta, burmistrza i prezydenta miasta, Dz.U. $2002 \mathrm{nr} 113$ poz. 984 [Direct elections of Borough Administrators and Mayors Act of 20 June 2002, Journal of Laws of the Republic of Poland No. 113 of 2002, item 984].

15 Ustawa z dnia 26 lipca 2002 r. o zmianie ustawy - ordynacja wyborcza do rad gmoin, rad powiatów i sejmików województw oraz zmianie niektórych innych ustaw, Dz.U. 2002 nr 127 poz. 1089 [Electoral Law for the Provincional, District and Sub-district Council Elections and amending other acts Act of July, 262002 amending the Act, Journal of Laws of the Republic of Poland No. 127 of 2002, item 1089]. 
were entrusted to the committee plenipotentiary). In addition, the function of provincial election commissioner was replaced by the electoral commissioners in number from 2 to 6 (in the province), defining their territorial jurisdiction. Two election commissioners, with their seats in Gdansk and Slupsk were appointed for the Pomeranian Province.

The d'Hondt method of allocating votes was reinstated, replacing SaintLague method that was introduced for parliamentary elections in 2001, which is favourable to smaller groups.

Preparation of local elections proceeded under specific conditions, i.e. shortening the term of office of regional councils and regional assemblies, and transfer the elections to spring 2002, the change of the number of seats in the district - these proposals were rejected.

It can be argued that the "election year 2002" was successful, since the municipal elections were conducted according to the electoral calendar. The procedure of introducing changes to the electoral law did not create favourable conditions for the growth of interest in the election. There was the lack of uniform concept concerning terms on which the elections should be held. Time of changes (during election year) and how the discussion was conducted, certainly had an influence for the participation in the elections on October 27, 2002; 13,078,372 voters exercised their voting rights $\left(29,572,225\right.$ were entitled to vote), voter turnout was $44.23 \% .{ }^{16} 505$ candidates registered in 58 electoral registers competed for 33 seats in the regional council; they were reported by the 13 election committees. Among registered election committees were five election committees of voters (electoral register No. $4,8,9,11,15$ ) and 8 party committees (Table 2).

The candidates representing the following party groups were only winners in the elections:

(a) Electoral Committee of the League of Polish Families - 3 seats

(b) Electoral Committee of the Self-Defence of Republic of Poland 6 seats

16 The Declaration of the National Electoral Commission of November 8, 2002 made the results of the councils elections across the country, public October 27, 2002, www. pkw.gov.pl/pkw2/indeks.jsp?place=Lead (February 19, 2010). 
(c) Coalition Electoral Committee of the Democratic Left AllianceLabour Union - 9 seats

(d) Electoral Committee of the Polish Peasant Party - 1 seat

(e) Coalition Electoral Committee of the Civic Platform-Law and Justice - 14 seats.

Representatives of the election committees of voters did not received the seat in the regional council. This defeat can be explained by unfavourable principles of the electoral law.

The second term of regional assemblies and district councils was completed in October 2006. In accordance with electoral procedure it should start preparing to carry out the next local elections. The Sejm received two projects of changes in the electoral law: 1) proposed by the Civic Platform of Republic of Poland, assumed the change from a proportional election system into the majority election system (with the possibility of conducting two rounds of voting), establishing single-member constituencies, ${ }^{17}$ 2) proposed by Law and Justice - kept the principle of proportionality, but assumed to introduce an innovative solution, which consists of grouping the electoral lists in order to establish a joint result of the election for those deciding for creation of the bloc of committees. Allocation of votes to the seats was to rely on their converting using diversified factors. ${ }^{18}$

Finally, the Sejm adopted changes in electoral law by the Act of 6 September 2006 amending the Act on Electoral Law for the provincional, district and sub-district council elections. ${ }^{19}$

Introduction of the concept concerning grouping the lists of candidates in the local government units to organs with principle of proportionality was a significant change affecting the transformation of local government

17 Sejm, a draft bill amending Act on the Election Law - municipal councils, county councils and regional councils, Print No. 817.

18 Sejm, a draft bill amending the Act of July, 161998 Election law - to municipal councils, county councils and regional councils and the Act of June, 202002 on direct elections of heads of communes, mayors and presidents of cities, Print 818.

19 Ustawa z dnia 6 września 2006 r. o zmianie ustawy - ordynacja wyborcza do rad gmin, rad powiatów I sejmików województw, Dz.U. 2006 Nr 159 poz. 1127 [Electoral Law for the Provincional, District and Sub-district Council Elections Act of September 6, 2006 amending the Act, Journal of Laws of the Republic of Poland No. 159of 2006, item 1127. 
electoral system. Grouping of lists of candidates, came into being after an agreement, concluded by at least two election committees, in order to jointly participate in the distribution of seats between lists of candidates.

Only those groups of lists which obtained at least $10 \%$ and $15 \%$ of valid votes, in the scale of the given unit, and at least one of the lists of candidates included in the given group of lists achieved at least $5 \%$ of valid votes, can take part in the distribution of seats (Article 88 paragraph 3, 134 paragraph 3,162 paragraph 3 ). If the group achieved less than $15 \%$ (for the regional council) or $10 \%$ (for the county councils and boroughs over 20000 inhabitants) then the result for each list is established separately. Applying two methods of converting votes into seats - the d'Hondt method - inside group of lists, if they exceeded the electoral threshold of 5\% in the scale of the given unit - with the Saint-Lague method. ${ }^{20}$

Introduction of the principle of grouping the lists gave an advantage of obtaining seats for committees which are in the block, and which alone would have little or even no chance of getting seats. Moreover, this mechanism awarded bonuses for group of lists at the expense of parties that achieved the good or average result, but lower than the total result of the committees forming the group of lists. ${ }^{21}$

Regional Council Elections in Pomeranian Province that took place on November 12, 2006 led to choosing 33 councillors from among 495 candidates. The number of people eligible to vote increased by 59,092 (it was 1715542 in comparison with 2002). There were five designated constituencies in the province, 51 candidates were registered in total. In accordance with Article 64la, paragraph 1, 2 groups of lists were formed in order to jointly participate in the distribution of seats (they were formed by six electoral committees), the other eight committees participated independently in the elections (Table 3).

20 K. Kowalczyk, Ł.Tomczak, Wybory samorządowe w Szczecinie w 2006 roku, Szczecin 2008.

21 L. Nikolski, Polskie wybory do regionów, [in:] Samorząd terytorialny. Studium politologiczne, ed. J. Marszałek-Kawa, Toruń 2007, pp. 216-244; K. Kowalczyk, L. Tomczak, op. cit, pp. 1933-1942. 
The candidates were recruited mainly from the parties (10 committees +1 coalition election committee), only two Election Committees of Voters registered their candidates:

(1) The Electoral Committee of the Polish Peasant Party (KWPSL)

(2) The Electoral Committee of the League of Polish Families (KWLPR)

(3) The Electoral Committee of the National Party of Retirees and Pensioners (KWKPEiR)

(4) The Electoral Committee of Law and Justice (KWPiS)

(5) The Electoral Committee of the Civic Platform (KWPO RP)

(6) The Coalition Electoral Committee SDPL SLD + PD + UP - Left and Democrats (KKW)

(7) The Electoral Committee of the Self-Defence of the Republic of Poland (KWSRP)

(10) The Electoral Committee of National Rebirth of Poland (KWNOP)

(11) The Electoral Committee of Voters for the Defence of the Polish Nation (KWWONP)

(12) The Electoral Committee of Real Politics Union (KWUPR)

(13) The Electoral Committee of the Polish Labour Party (KWPPP)

(14) The Electoral Committee of Voters of LEFT-Young Socialists the Greens (KWW Left). ${ }^{22}$

The next local elections took place in 2010 - the year of the twentieth anniversary of the local government in Poland. The date was set for November 21 (second ballot $-5^{\text {th }}$ December). ${ }^{23}$ The electoral law rules were changed (the election law was amended seven times, during four-year term of office), among others: grouping / blocking of the electoral lists was abolished, opening hours of polling stations were changed: 8.00-22.00, the institution of "electoral plenipotentiary" was introduced.

22 http://wybory2006.pkw.gov.pl/kbw/wynikiSejmik.html?jdn=220000 (19.01.2010).

23 Rozporządzenie Prezesa Rady Ministrów z dnia 17 września 2010 r. w sprawie zarządzenia wyborów do rad gmin, rad powiatów i sejmików województw, Rady m.st. Warszawy i rad dzielnic m.st. Warszawy oraz wyborów wójtów, burmistrzów i prezydentów 
Electoral plenipotentiary - a person entered into the municipal register of voters, after his designation by voter and completion with necessary formalities, he could take part in the elections with full voting rights. The right to transfer the power of attorney was granted to disabled persons, and people above the age of 75 (if they express their wish) (Article 40a-41h).

The division into five constituencies represented by 33 councillors remained the same in the Regional Council elections in Pomeranian Province. 526 candidates registered on 55 lists submitted by 14 electoral committees in 2010: 11 party electoral committees, 2 committees of voters and 1 committee of public organization (Table 4). The competition for 33 seats in the regional council took place between the candidates reported by the four party committees and an election committee of voters, because only their lists of candidates exceeded the required electoral threshold of $5 \%$. The distribution of the seats was as follows:

(1) The Electoral Committee of the Democratic Left Alliance (KW SLD) - 3 seats

(2) The Electoral Committee of the Polish Peasant Party (KW PSL) -3

(3) The Electoral Committee of the Civic Platform (KW PO RP) 19

(4) The Electoral Committee Law and Justice (KW PiS) - 7

(8) The Electoral Committee of Voters the National Local Government Community (KWW KWS) - 1

The voter turnout in the regional council elections was $46.69 \%$. Once again, on the basis of the results of the local elections at the regional level (province council) it was stated: a) the reluctance of voters to participate in the elections (although 65\% of respondents stated that local elections

miast, Dz.U. 2010 Nr 171, poz. 1151 [The Regulation of the Prime Minister of September, 172010 on the order of the Provincional, District and Sub-district Council Elections, the Council of the Capital City of Warsaw and Urban District Council; and elections of Borough Administrators and Mayors, Journal of Laws of the Republic of Poland No. 171 of 2010, item 1151]. 
are important, while $71 \%$ declared participation in elections), ${ }^{24} \mathrm{~b}$ ) the electoral system favours political parties rather than voters.

The electoral participation is dictated by the general principles of democratic political life. The parties with the greatest public support have the largest influence on generation of political life. The election results confirm conformity of the ideological assumptions to the public support. Acceptance of the directives of EU political life is revealed in the course of the political transformation.

Blurring the lines between the parties causes fluidity of policy options of citizens.

24 Centrum Badania Opinii Publicznej (CBOS) [Centre for Public Opinion Research], local elections - the importance, interest and declarations of participation, (BS/132/2010) Warsaw, September 2010, pp. 2-4. 
Table 1. Statistical data for the regional council elections in Pomeranian Province in 1998.

\begin{tabular}{|c|c|c|c|c|c|}
\hline $\begin{array}{l}\text { Consti- } \\
\text { tuency }\end{array}$ & $\begin{array}{c}\text { Electoral register num- } \\
\text { ber and Name of an } \\
\text { electoral committee }\end{array}$ & $\begin{array}{l}\text { Number of } \\
\text { candidates }\end{array}$ & $\begin{array}{l}\text { Number of } \\
\text { allocated } \\
\text { seats }\end{array}$ & $\begin{array}{l}\text { Number } \\
\text { of eligible } \\
\text { voters }\end{array}$ & $\begin{array}{l}\text { Voter } \\
\text { turnout }\end{array}$ \\
\hline \multirow[t]{2}{*}{ I } & $\begin{array}{ll}\text { (1) } & \text { SLD } \\
\text { (2) } & \text { AWS } \\
\text { (3) } & \text { UW } \\
\text { (4) } & \text { PS } \\
\text { (5) } & \text { ROP } \\
\text { (6) } & \text { RP } \\
\text { (8) } & \text { UPR } \\
\text { (9) } & \text { PZZ }\end{array}$ & $\begin{array}{l}7 \\
8 \\
6 \\
8 \\
5 \\
7 \\
5 \\
5\end{array}$ & $\begin{array}{l}2 \\
2 \\
0 \\
1 \\
0 \\
0 \\
0 \\
0\end{array}$ & 159,165 & $51,41 \%$ \\
\hline & $\begin{array}{l}7 \text { electoral registers have } \\
\text { been registered }\end{array}$ & 51 & 5 & & \\
\hline \multirow[t]{2}{*}{ II } & $\begin{array}{l}\text { (1) SLD } \\
\text { (2) AWS } \\
\text { (3) UW } \\
\text { (4) } \text { PS } \\
\text { (5) ROP } \\
\text { (6) RP } \\
\text { (7) UPR }\end{array}$ & $\begin{array}{r}10 \\
11 \\
11 \\
12 \\
8 \\
7 \\
6\end{array}$ & $\begin{array}{l}3 \\
2 \\
1 \\
0 \\
0 \\
0 \\
0\end{array}$ & 186,809 & $45,96 \%$ \\
\hline & $\begin{array}{l}7 \text { electoral registers have } \\
\text { been registered }\end{array}$ & 65 & 6 & & \\
\hline \multirow[t]{2}{*}{ III } & $\begin{array}{l}\text { (1) SLD } \\
\text { (2) AWS } \\
\text { (3) UW } \\
\text { (4) } \text { PS } \\
\text { (5) ROP } \\
\text { (6) RP } \\
\text { (7) } \text { Ch III RP } \\
\text { (8) UPR }\end{array}$ & $\begin{array}{r}10 \\
9 \\
10 \\
9 \\
6 \\
15 \\
8 \\
9\end{array}$ & $\begin{array}{l}1 \\
7 \\
1 \\
0 \\
0 \\
0 \\
0 \\
0\end{array}$ & 276,423 & $53,41 \%$ \\
\hline & $\begin{array}{l}8 \text { electoral registers have } \\
\text { been registered }\end{array}$ & 76 & 9 & & \\
\hline IV & $\begin{array}{l}\text { (1) SLD } \\
\text { (2) AWS } \\
\text { (3) UW }\end{array}$ & $\begin{array}{r}6 \\
11 \\
8\end{array}$ & $\begin{array}{l}2 \\
5 \\
0\end{array}$ & & \\
\hline
\end{tabular}




\begin{tabular}{|c|c|c|c|c|c|}
\hline $\begin{array}{l}\text { Consti- } \\
\text { tuency }\end{array}$ & $\begin{array}{c}\text { Electoral register num- } \\
\text { ber and Name of an } \\
\text { electoral committee }\end{array}$ & $\begin{array}{l}\text { Number of } \\
\text { candidates }\end{array}$ & $\begin{array}{l}\text { Number of } \\
\text { allocated } \\
\text { seats }\end{array}$ & $\begin{array}{l}\text { Number } \\
\text { of eligible } \\
\text { voters }\end{array}$ & $\begin{array}{c}\text { Voter } \\
\text { turnout }\end{array}$ \\
\hline \multirow[t]{2}{*}{$\mathrm{IV}(\mathrm{cd})$} & 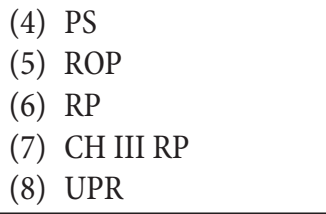 & $\begin{array}{r}7 \\
5 \\
13 \\
8 \\
7\end{array}$ & $\begin{array}{l}0 \\
0 \\
0 \\
0 \\
0\end{array}$ & 226,663 & $46,91 \%$ \\
\hline & $\begin{array}{l}8 \text { electoral registers have } \\
\text { been registered }\end{array}$ & 65 & 7 & & \\
\hline \multirow[t]{2}{*}{ V } & $\begin{array}{l}\text { (1) SLD } \\
\text { (2) AWS } \\
\text { (3) UW } \\
\text { (4) } \text { PS } \\
\text { (5) ROP } \\
\text { (6) RP } \\
\text { (7) } \text { Ch III RP } \\
\text { (8) UPR }\end{array}$ & $\begin{array}{r}8 \\
10 \\
6 \\
7 \\
7 \\
8 \\
8 \\
7\end{array}$ & $\begin{array}{l}2 \\
3 \\
1 \\
0 \\
0 \\
0 \\
0 \\
0\end{array}$ & 178,317 & $41,18 \%$ \\
\hline & $\begin{array}{l}8 \text { electoral registers have } \\
\text { been registered }\end{array}$ & 61 & 6 & & \\
\hline \multirow[t]{2}{*}{ VI } & $\begin{array}{l}\text { (1) SLD } \\
\text { (2) AWS } \\
\text { (3) UW } \\
\text { (4) } \text { PS } \\
\text { (5) ROP } \\
\text { (6) RP } \\
\text { (7) } \text { Ch III RP } \\
\text { (8) UPR }\end{array}$ & $\begin{array}{r}8 \\
6 \\
6 \\
7 \\
5 \\
10 \\
7 \\
10\end{array}$ & $\begin{array}{l}1 \\
3 \\
1 \\
0 \\
0 \\
0 \\
0 \\
0\end{array}$ & 176,073 & $41,18 \%$ \\
\hline & $\begin{array}{l}8 \text { electoral registers have } \\
\text { been registered }\end{array}$ & 59 & 5 & & \\
\hline VII & $\begin{array}{l}\text { (1) SLD } \\
\text { (2) AWS } \\
\text { (3) UW } \\
\text { (4) } \text { PS } \\
\text { (5) ROP } \\
\text { (6) RP } \\
\text { (7) } \text { Ch III RP } \\
\text { (8) UPR }\end{array}$ & $\begin{array}{l}9 \\
7 \\
7 \\
9 \\
5 \\
8 \\
7 \\
7\end{array}$ & $\begin{array}{l}2 \\
4 \\
0 \\
1 \\
0 \\
0 \\
0 \\
0\end{array}$ & 218,093 & $45,88 \%$ \\
\hline
\end{tabular}




\begin{tabular}{|c|c|c|c|c|c|}
\hline $\begin{array}{l}\text { Consti- } \\
\text { tuency }\end{array}$ & $\begin{array}{l}\text { Electoral register num- } \\
\text { ber and Name of an } \\
\text { electoral committee }\end{array}$ & $\begin{array}{l}\text { Number of } \\
\text { candidates }\end{array}$ & $\begin{array}{l}\text { Number of } \\
\text { allocated } \\
\text { seats }\end{array}$ & $\begin{array}{l}\text { Number } \\
\text { of eligible } \\
\text { voters }\end{array}$ & $\begin{array}{c}\text { Voter } \\
\text { turnout }\end{array}$ \\
\hline & $\begin{array}{l}8 \text { electoral registers have } \\
\text { been registered }\end{array}$ & 59 & 7 & & \\
\hline \multirow[t]{2}{*}{ VIII } & $\begin{array}{l}\text { (1) SLD } \\
\text { (2) AWS } \\
\text { (3) UW } \\
\text { (4) } \text { PS } \\
\text { (5) ROP } \\
\text { (6) RP } \\
\text { (7) } \text { Ch III RP } \\
\text { (8) UPR }\end{array}$ & $\begin{array}{r}6 \\
6 \\
10 \\
8 \\
6 \\
5 \\
5 \\
5\end{array}$ & $\begin{array}{l}3 \\
1 \\
1 \\
0 \\
0 \\
0 \\
0 \\
0\end{array}$ & 160,459 & $47,39 \%$ \\
\hline & $\begin{array}{l}8 \text { electoral registers have } \\
\text { been registered }\end{array}$ & 51 & 5 & & \\
\hline Total & $\begin{array}{l}63 \text { electoral registers } \\
\text { have been registered }\end{array}$ & 487 & 50 & $1,582,007$ & $47,39 \%$ \\
\hline
\end{tabular}

Source: Own study based on the statistical data issued by the State Election Commission.

Table 2. Statistical data for the regional council elections in Pomeranian Province in 2002.

\begin{tabular}{|c|l|c|c|c|c|}
\hline $\begin{array}{c}\text { Consti- } \\
\text { tuency }\end{array}$ & $\begin{array}{c}\text { Electoral register } \\
\text { number and Name of } \\
\text { an electoral committee }\end{array}$ & $\begin{array}{c}\text { Number of } \\
\text { candidates }\end{array}$ & $\begin{array}{c}\text { Number of } \\
\text { allocated } \\
\text { seats }\end{array}$ & $\begin{array}{c}\text { Number of } \\
\text { eligible } \\
\text { voters }\end{array}$ & $\begin{array}{c}\text { Voter } \\
\text { turnout }\end{array}$ \\
\hline \multirow{5}{*}{ (1) KWLPR } & 13 & 1 & & \\
& (2) KWSRP & 11 & 2 & & \\
& (3) KKWSLD-UP & 14 & 2 & & \\
& (4) KKWWUS & 7 & 0 & & \\
& (5) KWAPP & 7 & 0 & & \\
I & (6) KWPSL & 11 & 1 & \multirow{2}{*}{363,185} & \\
& (7) KWK-LPUPR & 7 & 0 & & \\
& (8) KWWAP & 5 & 0 & & \\
& (9) KWWKROB RP & 5 & 0 & & \\
& (10) KKWPO-PiS & 14 & 1 & & \\
& (11) KWWRP & 7 & 0 & & \\
& (12) KWKPEiR & 14 & 0 & & \\
\hline
\end{tabular}




\begin{tabular}{|c|c|c|c|c|c|}
\hline $\begin{array}{l}\text { Consti- } \\
\text { tuency }\end{array}$ & $\begin{array}{c}\text { Electoral register } \\
\text { number and Name of } \\
\text { an electoral committee }\end{array}$ & $\begin{array}{l}\text { Number of } \\
\text { candidates }\end{array}$ & $\begin{array}{c}\text { Number of } \\
\text { allocated } \\
\text { seats }\end{array}$ & $\begin{array}{c}\text { Number of } \\
\text { eligible } \\
\text { voters }\end{array}$ & $\begin{array}{c}\text { Voter } \\
\text { turnout }\end{array}$ \\
\hline & $\begin{array}{l}12 \text { electoral registers } \\
\text { have been registered }\end{array}$ & 115 & 7 & & \\
\hline \multirow[t]{2}{*}{ II } & $\begin{array}{l}\text { (1) KWLPR } \\
\text { (2) KWSRP } \\
\text { (3) KKWSLD-UP } \\
\text { (4) KKWWUS } \\
\text { (6) KWPSL } \\
\text { (7) KWK-LPUPR } \\
\text { (8) KWWAP } \\
\text { (9) KWWKROB RP } \\
\text { (10) KKWPO-PiS } \\
\text { (11) KWWRP } \\
\text { (12) KWKPEiR }\end{array}$ & $\begin{array}{r}16 \\
8 \\
13 \\
8 \\
9 \\
8 \\
6 \\
6 \\
15 \\
6 \\
15\end{array}$ & $\begin{array}{l}1 \\
1 \\
2 \\
0 \\
0 \\
0 \\
0 \\
4 \\
0 \\
0\end{array}$ & 412,313 & $45,25 \%$ \\
\hline & $\begin{array}{l}11 \text { electoral registers } \\
\text { have been registered }\end{array}$ & 110 & 8 & & \\
\hline \multirow[t]{2}{*}{ III } & $\begin{array}{l}\text { (1) KWLPR } \\
\text { (2) KWSRP } \\
\text { (3) KKWSLD-UP } \\
\text { (4) KKWWUS } \\
\text { (5) KWAPP } \\
\text { (6) KWPSL } \\
\text { (7) KWK-LPUPR } \\
\text { (8) KWWAP } \\
\text { (9) KWWKROB RP } \\
\text { (10) KKWPO-PiS } \\
\text { (11) KWWRP } \\
\text { (12) KWKPEiR }\end{array}$ & $\begin{array}{r}12 \\
9 \\
14 \\
7 \\
7 \\
6 \\
9 \\
6 \\
6 \\
13 \\
5 \\
14\end{array}$ & $\begin{array}{l}1 \\
0 \\
2 \\
0 \\
0 \\
0 \\
0 \\
0 \\
0 \\
4 \\
0 \\
0\end{array}$ & 359,525 & $34,64 \%$ \\
\hline & $\begin{array}{l}12 \text { electoral registers } \\
\text { have been registered }\end{array}$ & 108 & 7 & & \\
\hline IV & $\begin{array}{l}\text { (1) KWLPR } \\
\text { (2) KWSRP } \\
\text { (3) KKWSLD-UP } \\
\text { (4) KKWWUS } \\
\text { (5) KWAPP } \\
\text { (6) KWPSL } \\
\text { (7) KWK-LPUPR } \\
\text { (8) KWWAP }\end{array}$ & $\begin{array}{r}6 \\
9 \\
10 \\
6 \\
6 \\
11 \\
7 \\
5\end{array}$ & $\begin{array}{l}0 \\
2 \\
1 \\
0 \\
0 \\
0 \\
0 \\
0\end{array}$ & & \\
\hline
\end{tabular}




\begin{tabular}{|c|c|c|c|c|c|}
\hline $\begin{array}{l}\text { Consti- } \\
\text { tuency }\end{array}$ & $\begin{array}{c}\text { Electoral register } \\
\text { number and Name of } \\
\text { an electoral committee }\end{array}$ & $\begin{array}{l}\text { Number of } \\
\text { candidates }\end{array}$ & $\begin{array}{l}\text { Number of } \\
\text { allocated } \\
\text { seats }\end{array}$ & $\begin{array}{l}\text { Number of } \\
\text { eligible } \\
\text { voters }\end{array}$ & $\begin{array}{l}\text { Voter } \\
\text { turnout }\end{array}$ \\
\hline \multirow[t]{2}{*}{$\mathrm{IV}(\mathrm{cd})$} & $\begin{array}{l}\text { (9) KWWKROB RP } \\
\text { (10) KKWPO-PiS } \\
\text { (11) KWWRP } \\
\text { (12) KWKPEiR }\end{array}$ & $\begin{array}{r}6 \\
11 \\
5 \\
11\end{array}$ & $\begin{array}{l}0 \\
3 \\
0 \\
0\end{array}$ & 267,662 & $52,24 \%$ \\
\hline & $\begin{array}{l}12 \text { electoral registers } \\
\text { have been registered }\end{array}$ & 93 & 6 & & \\
\hline \multirow[t]{2}{*}{ V } & $\begin{array}{l}\text { (1) KWLPR } \\
\text { (2) KWSRP } \\
\text { (3) KKWSLD-UP } \\
\text { (4) KKWWUS } \\
\text { (5) KWAPP } \\
\text { (6) KWPSL } \\
\text { (7) KWK-LPUPR } \\
\text { (8) KWWAP } \\
\text { (10) KKWPO-PiS } \\
\text { (12) KWKPEiR } \\
\text { (13) KWWPT-A2002 }\end{array}$ & $\begin{array}{r}5 \\
8 \\
9 \\
5 \\
6 \\
8 \\
7 \\
5 \\
10 \\
10 \\
6\end{array}$ & $\begin{array}{l}0 \\
1 \\
2 \\
0 \\
0 \\
0 \\
0 \\
0 \\
2 \\
0 \\
0\end{array}$ & 253,765 & $44,98 \%$ \\
\hline & $\begin{array}{l}\text { 113electoral registers } \\
\text { have been registered }\end{array}$ & 79 & 5 & & \\
\hline Total & $\begin{array}{l}58 \text { electoral registers } \\
\text { have been registered }\end{array}$ & 505 & 33 & $1,656,450$ & $44,42 \%$ \\
\hline
\end{tabular}

Source: Own study based on the statistical data issued by the State Election Commission.

Table 3. Statistical data for the regional council elections in Pomeranian Province in 2006.

\begin{tabular}{|c|l|c|c|c|c|}
\hline $\begin{array}{c}\text { Consti- } \\
\text { tuency }\end{array}$ & $\begin{array}{c}\text { Electoral register } \\
\text { number and Name of } \\
\text { an electoral committee }\end{array}$ & $\begin{array}{c}\text { Number of } \\
\text { candidates }\end{array}$ & $\begin{array}{c}\text { Number of } \\
\text { allocated } \\
\text { seats }\end{array}$ & $\begin{array}{c}\text { Number of } \\
\text { eligible } \\
\text { voters }\end{array}$ & $\begin{array}{c}\text { Voter } \\
\text { turnout }\end{array}$ \\
\hline \multirow{5}{*}{ I } & (1) KWPSL & 7 & 1 & & \\
& (2) KWLPR & 14 & 0 & & \\
& (3) KWKPEiR & 11 & 0 & & \\
& (4) KWPiS & 14 & 1 & & \\
& (5) KWPO RP & 14 & 3 & & \\
& (6) KKW & 8 & 1 & & \\
\hline
\end{tabular}




\begin{tabular}{|c|c|c|c|c|c|}
\hline $\begin{array}{l}\text { Consti- } \\
\text { tuency }\end{array}$ & $\begin{array}{c}\text { Electoral register } \\
\text { number and Name of } \\
\text { an electoral committee }\end{array}$ & $\begin{array}{l}\text { Number of } \\
\text { candidates }\end{array}$ & $\begin{array}{c}\text { Number of } \\
\text { allocated } \\
\text { seats }\end{array}$ & $\begin{array}{l}\text { Number of } \\
\text { eligible } \\
\text { voters }\end{array}$ & $\begin{array}{l}\text { Voter } \\
\text { turnout }\end{array}$ \\
\hline \multirow[t]{2}{*}{ I } & $\begin{array}{l}\text { (7) KWSRP } \\
\text { (10) KWNOP } \\
\text { (12) KWUPR } \\
\text { Group A } \\
\text { (3) KWKPEiR } \\
\text { (5) KWPO RP } \\
\text { Group B } \\
\text { (1) KWPSL } \\
\text { (2) KWLPR } \\
\text { (4) KWPiS } \\
\text { (7) KWSRP }\end{array}$ & $\begin{array}{c}14 \\
6 \\
6 \\
------ \\
11 \\
14 \\
----- \\
7 \\
14 \\
14 \\
14\end{array}$ & $\begin{array}{c}1 \\
0 \\
0 \\
-10 \\
0 \\
3 \\
---- \\
1 \\
0 \\
1 \\
1\end{array}$ & 347,413 & $45,73 \%$ \\
\hline & $\begin{array}{l}9 \text { electoral registers } \\
\text { have been registered }\end{array}$ & 94 & 7 & & \\
\hline \multirow[t]{3}{*}{ II } & $\begin{array}{l}\text { (1) KWPSL } \\
\text { (2) KWLPR } \\
\text { (3) KWKPEiR } \\
\text { (4) KWPiS } \\
\text { (5) KWPO RP } \\
\text { (6) KKW } \\
\text { (7) KWSRP } \\
\text { (10) KWNOP } \\
\text { (11) KWWONP } \\
\text { (12) KWUPR } \\
\text { Group A } \\
\text { (3) KWKPEiR } \\
\text { (5) KWPO RP } \\
\text { Group B } \\
\text { (1) KWPSL } \\
\text { (2) KWLPR } \\
\text { (4) KWPiS } \\
\text { (7) KWSRP }\end{array}$ & $\begin{array}{r}13 \\
16 \\
12 \\
16 \\
16 \\
10 \\
16 \\
5 \\
6 \\
6 \\
----- \\
12 \\
16 \\
----- \\
13 \\
16 \\
16 \\
16\end{array}$ & $\begin{array}{l}0 \\
0 \\
0 \\
3 \\
5 \\
0 \\
0 \\
0 \\
0 \\
0 \\
---- \\
0 \\
5 \\
----- \\
0 \\
0 \\
3 \\
0\end{array}$ & 428,015 & $49,64 \%$ \\
\hline & $\begin{array}{l}10 \text { electoral registers } \\
\text { have been registered }\end{array}$ & 87 & 8 & & \\
\hline & $\begin{array}{l}\text { (1) KWPSL } \\
\text { (2) KWLPR } \\
\text { (3) KWKPEiR }\end{array}$ & $\begin{array}{l}10 \\
14 \\
13\end{array}$ & $\begin{array}{l}0 \\
0 \\
0\end{array}$ & & \\
\hline
\end{tabular}




\begin{tabular}{|c|c|c|c|c|c|}
\hline $\begin{array}{l}\text { Consti- } \\
\text { tuency }\end{array}$ & $\begin{array}{c}\text { Electoral register } \\
\text { number and Name of } \\
\text { an electoral committee }\end{array}$ & $\begin{array}{l}\text { Number of } \\
\text { candidates }\end{array}$ & $\begin{array}{c}\text { Number of } \\
\text { allocated } \\
\text { seats }\end{array}$ & $\begin{array}{l}\text { Number of } \\
\text { eligible } \\
\text { voters }\end{array}$ & $\begin{array}{c}\text { Voter } \\
\text { turnout }\end{array}$ \\
\hline \multirow[t]{2}{*}{ III } & $\begin{array}{l}\text { (4) KWPiS } \\
\text { (5) KWPO RP } \\
\text { (6) KKW } \\
\text { (7) KWSRP } \\
\text { (10) KWNOP } \\
\text { (11) KWWONP } \\
\text { (12) KWUPR } \\
\text { (13) KWPPP } \\
\text { (14) KWWLewica } \\
\text { Group A } \\
\text { (3) KWKPEiR } \\
\text { (5) KWPO RP } \\
\text { Group B } \\
\text { (1) KWPSL } \\
\text { (2) KWLPR } \\
\text { (4) KWPiS } \\
\text { (7) KWSRP }\end{array}$ & $\begin{array}{r}14 \\
14 \\
11 \\
14 \\
5 \\
12 \\
5 \\
6 \\
7 \\
------ \\
13 \\
14 \\
------ \\
10 \\
14 \\
14 \\
14\end{array}$ & $\begin{array}{l}2 \\
5 \\
0 \\
0 \\
0 \\
0 \\
0 \\
0 \\
0 \\
----- \\
0 \\
5 \\
----- \\
0 \\
0 \\
2 \\
0\end{array}$ & 361,462 & $44,39 \%$ \\
\hline & $\begin{array}{l}12 \text { electoral registers } \\
\text { have been registered }\end{array}$ & 125 & 7 & & \\
\hline IV & $\begin{array}{l}\text { (1) KWPSL } \\
\text { (2) KWLPR } \\
\text { (3) KWKPEiR } \\
\text { (4) KWPiS } \\
\text { (5) KWPO RP } \\
\text { (6) KKW } \\
\text { (7) KWSRP } \\
\text { (10) KWNOP } \\
\text { (11) KWWONP } \\
\text { (12) KWUPR } \\
\text { Group A } \\
\text { (3) KWKPEiR } \\
\text { (5) KWPO RP } \\
\text { Group B } \\
\text { (1) KWPSL } \\
\text { (2) KWLPR } \\
\text { (4) KWPiS } \\
\text { (7) KWSRP }\end{array}$ & $\begin{array}{r}7 \\
12 \\
7 \\
12 \\
11 \\
9 \\
11 \\
6 \\
9 \\
5 \\
----- \\
7 \\
11 \\
----- \\
7 \\
12 \\
12 \\
11\end{array}$ & $\begin{array}{l}0 \\
0 \\
0 \\
2 \\
3 \\
0 \\
1 \\
0 \\
0 \\
0 \\
----- \\
0 \\
3 \\
----- \\
0 \\
0 \\
2 \\
1\end{array}$ & 287,739 & $50,34 \%$ \\
\hline
\end{tabular}




\begin{tabular}{|c|c|c|c|c|c|}
\hline $\begin{array}{l}\text { Consti- } \\
\text { tuency }\end{array}$ & $\begin{array}{c}\text { Electoral register } \\
\text { number and Name of } \\
\text { an electoral committee }\end{array}$ & $\begin{array}{l}\text { Number of } \\
\text { candidates }\end{array}$ & $\begin{array}{l}\text { Number of } \\
\text { allocated } \\
\text { seats }\end{array}$ & $\begin{array}{l}\text { Number of } \\
\text { eligible } \\
\text { voters }\end{array}$ & $\begin{array}{l}\text { Voter } \\
\text { turnout }\end{array}$ \\
\hline & $\begin{array}{l}10 \text { electoral registers } \\
\text { have been registered }\end{array}$ & 89 & 6 & & \\
\hline \multirow[t]{2}{*}{$\mathrm{V}$} & $\begin{array}{l}\text { (1) KWPSL } \\
\text { (2) KWLPR } \\
\text { (3) KWKPEiR } \\
\text { (4) KWPiS } \\
\text { (5) KWPO RP } \\
\text { (6) KKW } \\
\text { (7) KWSRP } \\
\text { (10) KWNOP } \\
\text { (11) KWWONP } \\
\text { (12) KWUPR } \\
\text { Group A } \\
\text { (3) KWKPEiR } \\
\text { (5) KWPO RP } \\
\text { Group B } \\
\text { (1) KWPSL } \\
\text { (2) KWLPR } \\
\text { (4) KWPiS } \\
\text { (7) KWSRP }\end{array}$ & $\begin{array}{r}10 \\
10 \\
9 \\
10 \\
10 \\
9 \\
10 \\
5 \\
7 \\
5 \\
---- \\
9 \\
10 \\
----- \\
10 \\
10 \\
10 \\
10 \\
\end{array}$ & $\begin{array}{l}1 \\
0 \\
0 \\
1 \\
2 \\
0 \\
1 \\
0 \\
0 \\
0 \\
---- \\
0 \\
2 \\
----- \\
1 \\
0 \\
1 \\
1 \\
\end{array}$ & 261,183 & $43,20 \%$ \\
\hline & $\begin{array}{l}10 \text { electoral registers } \\
\text { have been registered }\end{array}$ & 85 & 5 & & \\
\hline Total & $\begin{array}{l}51 \text { electoral registers } \\
\text { have been registered }\end{array}$ & 480 & 33 & $1,712,812$ & $46,66 \%$ \\
\hline
\end{tabular}

Source: Own study based on the statistical data issued by the State Election Commission.

Table 4. Statistical data for the regional council elections in the Pomeranian Province in 2010

\begin{tabular}{|l|l|l|l|c|}
\hline $\begin{array}{c}\text { Electoral register number and } \\
\text { Name of an electoral committee }\end{array}$ & $\begin{array}{c}\text { Number of } \\
\text { candidates }\end{array}$ & $\begin{array}{c}\text { Number of } \\
\text { allocated seats }\end{array}$ & $\begin{array}{c}\text { Number } \\
\text { of eligi- } \\
\text { ble voters }\end{array}$ & $\begin{array}{c}\text { Voter } \\
\text { turnout }\end{array}$ \\
\hline (1) KW SLD & 60 & 3 & & \\
(2) KW PSL & 63 & 3 & & \\
\hline
\end{tabular}




\begin{tabular}{|c|c|c|c|c|}
\hline $\begin{array}{l}\text { Electoral register number and } \\
\text { Name of an electoral committee }\end{array}$ & $\begin{array}{l}\text { Number of } \\
\text { candidates }\end{array}$ & $\begin{array}{l}\text { Number of } \\
\text { allocated seats }\end{array}$ & $\begin{array}{l}\text { Number } \\
\text { of eligi- } \\
\text { ble voters }\end{array}$ & $\begin{array}{l}\text { Voter } \\
\text { turnout }\end{array}$ \\
\hline $\begin{array}{l}\text { (3) KW POLSKA PARTIA PRACY } \\
\text { - SIERPIEN } 80 \\
\text { (4) KW PO RP } \\
\text { (5) KW PiS } \\
\text { (6) KW LPR } \\
\text { (7) KW PRAWICA } \\
\text { RZECZYPOSPOLITEJ } \\
\text { (8) KWW KWS } \\
\text { (9) KW KRAJOWA PARTIA } \\
\text { EMERYTÓW i RENCISTÓW } \\
\text { (10) KW NASZ DOM POLSKA- } \\
\text { SAMOOBRONA A.LEPPERA } \\
\text { (11) KW UPR } \\
\text { (12) KW EKOPARK } \\
\text { (13) KWW SOLIDARNY } \\
\text { GDAŃSK } \\
\text { (14) KWW RUCH WYBORCÓW } \\
\text { J.KORWIN-MIKKE }\end{array}$ & $\begin{array}{l}41 \\
66 \\
61 \\
30 \\
14 \\
33 \\
\\
64 \\
46 \\
\\
28 \\
6 \\
7 \\
7\end{array}$ & $\begin{array}{l}0 \\
19 \\
7 \\
0 \\
0 \\
1 \\
\\
0 \\
0 \\
0 \\
0 \\
0 \\
0 \\
0 \\
0\end{array}$ & & \\
\hline $\begin{array}{l}55 \text { electoral registers have been } \\
\text { registered }\end{array}$ & 526 & 33 & $1,755,202$ & $46,69 \%$ \\
\hline
\end{tabular}

Source: Own study based on the statistical data issued by the State Election Commission. 